\title{
KEY COMPETENCES - INVESTMENT IN HUMAN CAPITAL WITHIN OUT-OF-SCHOOL EDUCATION FORMS
}

\author{
Małgorzata SKWERES-KUCHTA \\ University of Szczecin; malgorzata.skweres-kuchta@usz.edu.pl, ORCID: 0000-0002-0540-5416
}

\begin{abstract}
Purpose: The aim of the research is to show how effective the tools in the form of extracurricular forms of education oriented at development of key competences.

Design/methodology/approach: The article presents case study of investment in key competences of school-age children. The results of evaluation studies compliment the experience of chosen out-od-school educational projects conducted in the district mostly active in the field of initiative realization. The author also mentions a problem of considering and fulfilling children's special educational needs.

Findings: In the educational projects implemented in Pomeranian Voivodeship, the main emphasis was placed on the development of key competences, mostly students, and to a lesser extent - teachers. The interest in particular competences varied (39-95\%). Similarly, the effects of undertaken measures were assessed as their impact on the attitudes of students in selected areas.
\end{abstract}

Research limitations/implications: Too little attention paid to the special needs of pupils. Evaluation of effectiveness referred to the influence of particular forms of stimulation on the student's attitude in selected aspects. It was impossible to clearly attribute the impact of the investment on the results of exams summarizing a given stage of learning.

Practical implications: The results of the research can be used to change the guidelines for constructing further support programmes for educational projects. This refers to technical guidelines, i.e. the formula for verifying the effects and the substantive ones, i.e. The scope of support for schools and students.

Social implications: The work points to the need to implement solutions allowing for greater social inclusion of children with special news, including work on social awareness in this area. Originality/value The article attempts to assess the effectiveness of investing in the development of human capital at the stage of school education through extracurricular educational projects. The analysis was multi-level, from the European background, through the regional approach in Poland, to case studies in selected local governments. The results of the research may serve to construct further pro-educational projects in the region.

Keywords: Human capital, competence management, key competences, special educational needs.

Category of the paper: Research paper, Case study. 


\section{Introduction}

The discussion on Polish educational system incessantly continues: outdated, inefficient, underfunded, underinvested, non-innovative, boring... These are conclusions deriving from analysis and diagnosis of requests for support in many Polish schools. Due to the fact that investment in human capital is a pillar of the EU's financial policy, the author decided to analyze forms and effects of the projects increasing competences within regional operational programs, focusing on children and teenagers. An incentive for such an analysis were children universities, enthusiastically adopted by children and parents. The author has been leading one for several years (www.iniwersytet-dzieciecy.pl). The aim of the research is to verify, how effective was the investment for the development of human capital via education oriented at development of key competences.

\section{European Social Fund - a tool for investing in people}

European Social Fund (EFS) - first financial instrument of the European Union, one of the EU's five main funds - supports socio-economic development in member countries by investing in people. In a current perspective (2014-2020), the Fund's budget constitutes almost quarter of all EU's expenditures on regional development policy - it is amount of more than EUR 80 billion, excluding EU's members own contribution. The Fund is dedicated to investing in people, especially ones with problems with finding a job. Labor market is changing due to dynamic technological development, strive for sustainable development as well as nondiscrimination and equal opportunities. Therefore ESF supports also initiatives that stimulate professional future in the childhood. Consequently, education becomes one of the four areas supported with ESF's funds.

The Fund facilitates continuation of education in order to find job and develop professional career for the larger amount of young people. It also ensures wider access to high-quality education and allows to equal chances in the field of qualifications for disadvantaged children, including those living in rural areas. Such initiatives will be mentioned in the following article.

In Poland, ESF programs amounted to more than EUR 13 billion (Figure 1) and were higher by EUR 2 billion than 2007-2013 perspective ${ }^{1}$. Its distribution takes place on the two levels: national and regional. The first one - Operational Program Knowledge Education Development (Program Operacyjny Wiedza Edukacja Rozwój POWER), consumed approx. 1/3 of a total budget and concentrated on institutional frames and implemented reforms as well as areas with national range like young people support, higher education, social innovations and transnational

\footnotetext{
${ }^{1}$ Budget of ESF for the years 2007-2013 EUR 115 billion, 2014-2020 perspective - EUR 125 billion, considering member countries own contribution. Compare The European Social Fund. Investing in people, European Commission, 2016.
} 
cooperation. The rest of the budget was transferred to the self-governments of regional programs (RPO).This kind of decentralization of management aimed at bringing decision on projects financing closer to their main recipients in order to optimally fulfill social needs in a particular region. The article relates to the projects considering mentioned regional specificity.

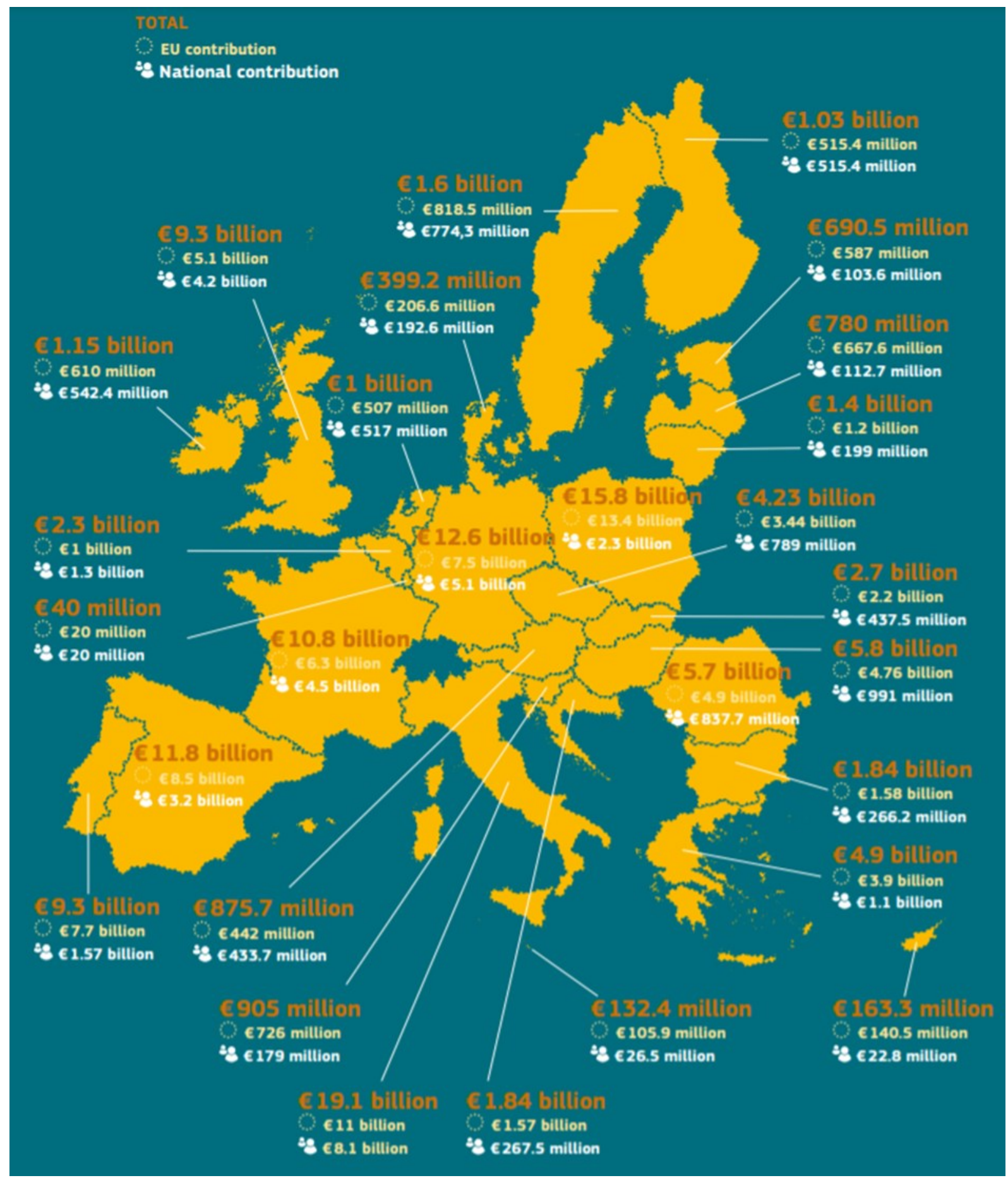

Figure 1. ESF budget per EU country, 2014-2020. Adaptet from: The European Social Fund. Investing in people, European Commission, 2016, p. 20. 
Activities aimed at improving access to education and improving its quality play an important role among the priorities of particular ROP. Intensive support is directed to schools, especially in the field of students' equal educational chances, equipping didactic and scientific base, teachers' education and training.

ESF serves people representing various social groups. Regional strategies of socioeconomic development outlined the frames of regional interventions, while particular projects provided detailed local needs on the basis of conducted diagnosis of particular social group's needs. The following article presents examples of self-government administration beneficiaries, whose projects focused on students from primary and secondary schools.

\section{Competency-based human resource management}

The concept of competences is tightly related to the human resource management. Strategic aim of such management is gaining and developing highly competitive people. Those people will effectively achieve their goals and consequently contribute to achieving goals by the organization (Armstrong, 2001). Choosing from many definitions of "competences" concept, the one of the M. Armstrong can be brought up that competency is the potential that contributes to the achievement of desired objectives. This potential consists of knowledge, skills and attitude - widely understood, referring to the patience, persistence, flexibility, self-confidence, motivation, readiness for action (Sienkiewicz, 2013).

As Dubois D.D. and Rothwell W.J. (2008) underline "No competencies, no performance, no organization". Therefore there was a change in approach to human resource management, from one based on structure towards management based on competencies. Competency-based human resources management has been actively developing since the beginning of the 1990s (in the USA and Western European countries). One advantage of constructing competency management systems is the possibility of integrating all areas of human resources management on the basis of a competency-based approach. Among different models of human resources management, the competency-based approach is especially close to the idea of lifelong learning, which focuses on an individual as its main point of reference. In the competency-based approach, the point of reference is the employee who holds a specific job and not the job itself (Sienkiewicz, 2013).

The coming (current - the author's footnote) time is the time of a mental employee who, in addition to formal education, has the ability to apply knowledge in practice and the habit of continuous learning. Considering Peter Drucker's words (1994), to build competitiveness on 
a labor market it is essential to invest in the development of competences. Which ones? The European Commission (2006) answers - key competences, where key competences are ${ }^{2}$ :

- Communicating in a mother tongue and in a foreign language.

- Mathematical, scientific and technological competence.

- Digital competence.

- Learning to learn.

- Social and civic competences.

- Sense of initiative and entrepreneurship.

- Cultural awareness and expression.

Due to the European Commission, mentioned set of competencies is essential for selfrealization, being active citizen, social coherency and gaining employment in the knowledge society. Self-governments which conducted projects increasing quality of education and financed with regional operational programs of current financial perspective 2014-2020, improvement in focused on investing in the set of competences mentioned above. It should be underlined that in the economic practice as well as in academic discussion, the dispute over how to manage human capital to most adequately correlate with the organization's results (Armstrong, Brown, 2019).

In conclusion, the development of human capital requires resources, which are lacking in the Polish education system. The support is provided by finances from the EU budget, and their use is possible if educational projects are fully in line with the development strategy of the Community.

\section{Key competences - object of investment in people in Pomeranian Voivodeship}

For the purposes of this article, an attempt of investment effectiveness appraisal has been taken up on the basis of data from Pomeranian region, as the Pomeranian Voivodeship is a leader in the exploitation of Regional Operational Programs' funds - it utilized more than $82 \%$ of allocation so far (Figure 2).

Starting point for program implementation was unsatisfactory quality level of education on its every step. The improvement of the quality became a particular aim in this area of intervention. According to the diagnosis, external results of exams of Pomeranian schools' pupils remained below national average, especially in schools in small towns and rural areas. Therefore recognized priorities were limitation of early school leaving and ensuring equal

\footnotetext{
2 The author of the article wrote about the knowledge employees and influence of key competences on the economic maturity in: Investment in key competences development among children and teenagers - case study, Ekonomiczne Problemy Usług no 4/2017 (129), p. 245.
} 
access to of a good quality elementary education, primary and higher education ${ }^{3}$. In the face of numerous challenges related to the implemented changes in education, specially important was development of effective mechanisms of support for teachers, including improving the quality of their work. The lack of objective and subjective nets of teachers cooperation was additional difficulty. Also the schools merely cooperated with the surroundings that could have positively influenced the quality of education process.
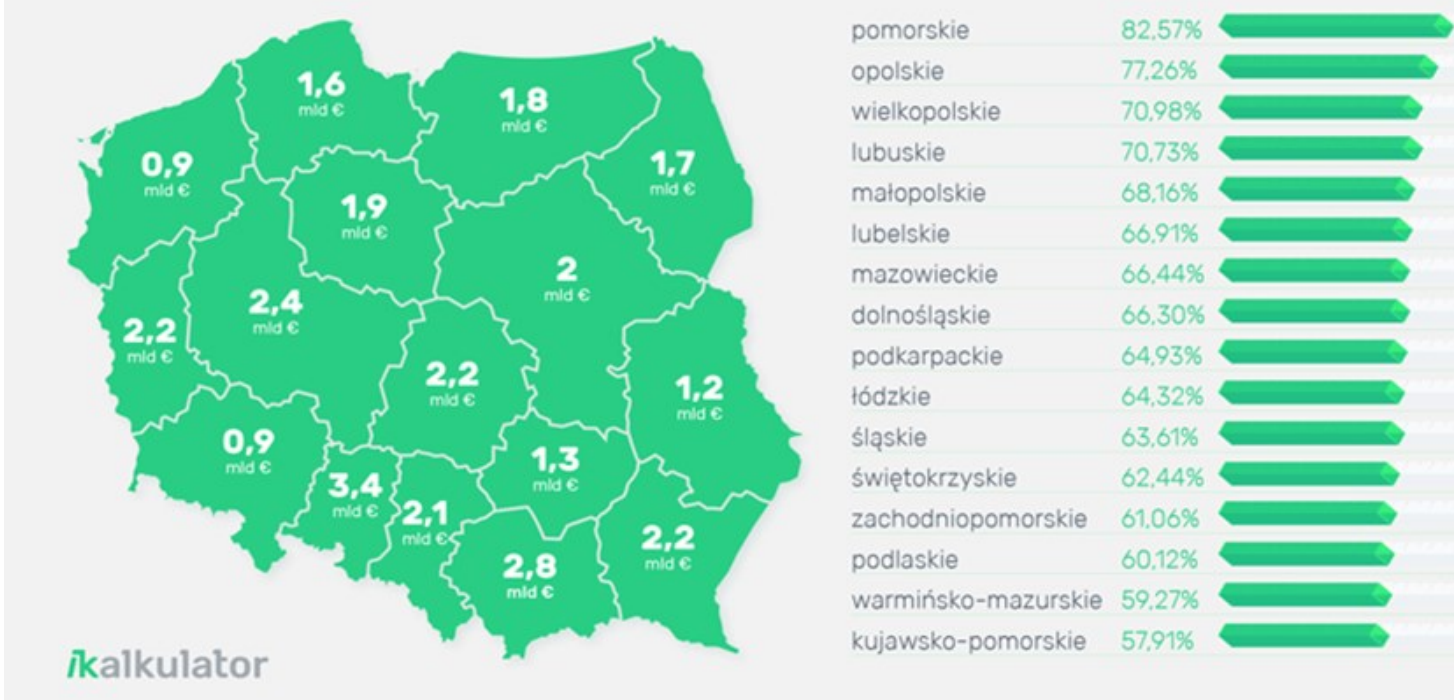

Figure 2. European funds 2014-2020 - which voivodeships utilize EU's donations the most effectively? Adapted from: https://www.portalsamorzadowy.pl/fundusze-europejskie/wojewodztwo-pomorskieliderem-w-realizacji-regionalnego-programu-operacyjnego, 123705.html, access on 2019-08-24.

To achieve abovementioned goal, a comprehensive support of schools was set up to ultimately strengthen student's key competences necessary on the labor market. The goal was to be achieved through action on three main levels: improvements of facilities, improvement classes for teachers and for students ${ }^{4}$. Types and scope of support implemented in region, broke down into types of municipalities, presents Figure 3.

The final support (within action 3.2.1) went to 757 schools and institutions ( $40 \%$ of the total number of schools in the region) and covered $71 \%$ of municipalities in the region, $44 \%$ of districts and all cities with district status (Figure 3). Municipalities were the main beneficiaries of the support (except cities with district status) $-73 \%$ of all implemented projects. Primary and lower school education were the most supported $-66 \%$ and $51 \%$ of all schools in the region, respectively. Over 86.000 of students was included, whereas $57 \%$ were children in the age of $7-12$ years, $12 \%$ in the age of 13-15 years. The author's reflections will be focused on this particular group in the following part of the article. What is interesting, only $26 \%$ of special institutions were interested in gaining support. The most, $43 \%$ of supported schools operated in the area of rural municipalities.

\footnotetext{
${ }^{3}$ Regional Operational Program of Pomeranian Voivodeship for the years 2014-2020, p. 51.

${ }^{4}$ Detailed Description of Priority Axis of Regional Operational Program of Pomeranian Voivodeship for the years 2014-2020, p. 39.
} 


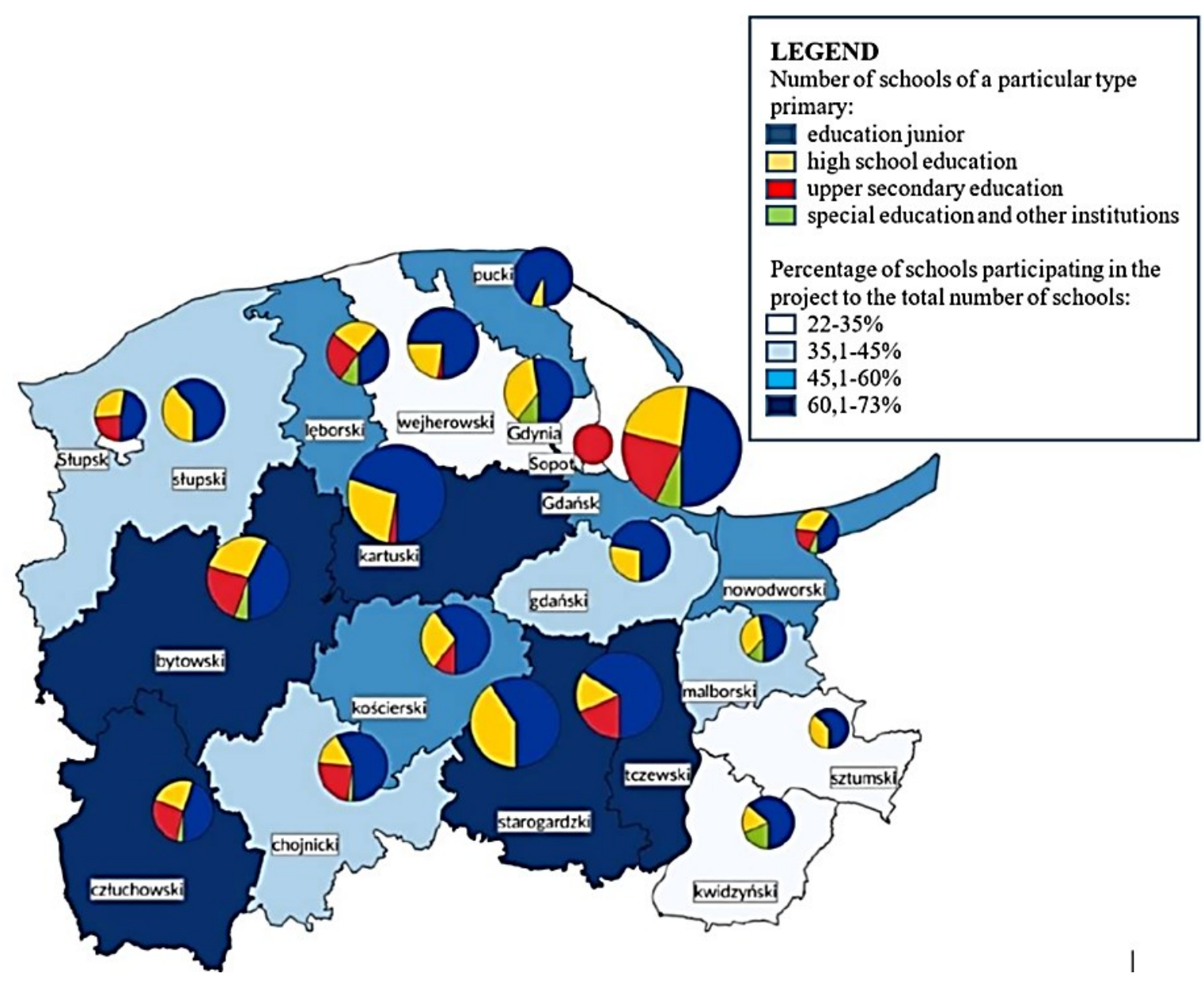

Figure 3. Project activity by districts. Adapted from: Assessment of efficiency and effectiveness of support provided under the sub-measure 3.2.1. Quality of general education Regional Operational Program of Pomeranian Voivodeship for the years 2014-2020. Final report, EVALU Sp. z o.o., Gdańsk 2018, p. 29

In all municipalities the main emphasis was placed on the development of key competences $^{5}$. Right after them, creativity and innovation as well as career counselling were developed (albeit to the lesser extent than in previous financial perspective). Attention was also focused on supporting students with special education needs (Figure 4).

\footnotetext{
5 The range of key competences supported within the program is narrower than the one defined in RECOMMENDATION OF THE EUROPEAN PARLIAMENT AND OF THE COUNCIL of 18 December 2006 on key competences for lifelong learning (2006/962/EC), it doesn't cover communication in a mother tongue as well as consciousness and cultural expression. Compare: Competition regulations of 26.11.2015 (Attachment 11). In evaluation study, responders pointed out this shortcoming as a drawback of the competition. Compare p. 72.
} 


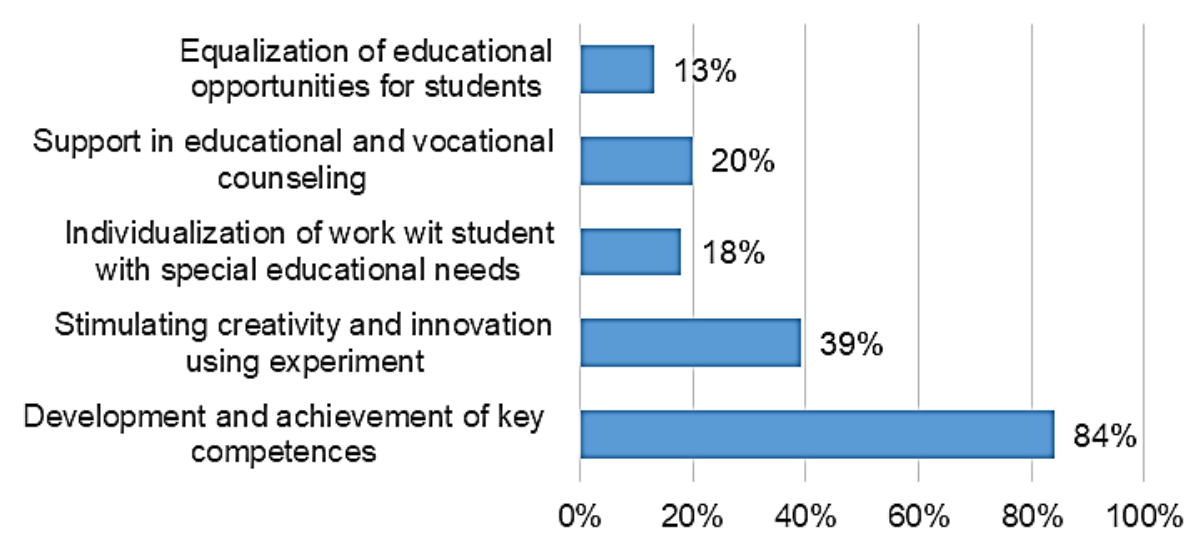

Figure 4. Percentage of students planned to be supported by the type of support. Adapted from: Assessment of efficiency and effectiveness of support provided under the sub-measure 3.2.1. Quality of general education Regional Operational Program of Pomeranian Voivodeship for the years 2014-2020. Final report, EVALU Sp. z o.o., Gdańsk 2018, p. 38.

Which competences were the most important for students? In almost all cases, interest was very high (Figure 5). In both age groups, the vast majority of children - more than $90 \%$, were educated in the field of competencies in mathematics, social engineering, only a little bit less in language and digital competences. Although initiative attitude and entrepreneurship enjoyed the least interest (or there was the poorest offer in those fields), mentioned competences were supplemented with other activities related to stimulating creativity and innovation. It should also be noted that the need for development in this area increased with age, similarly to the learning competences.

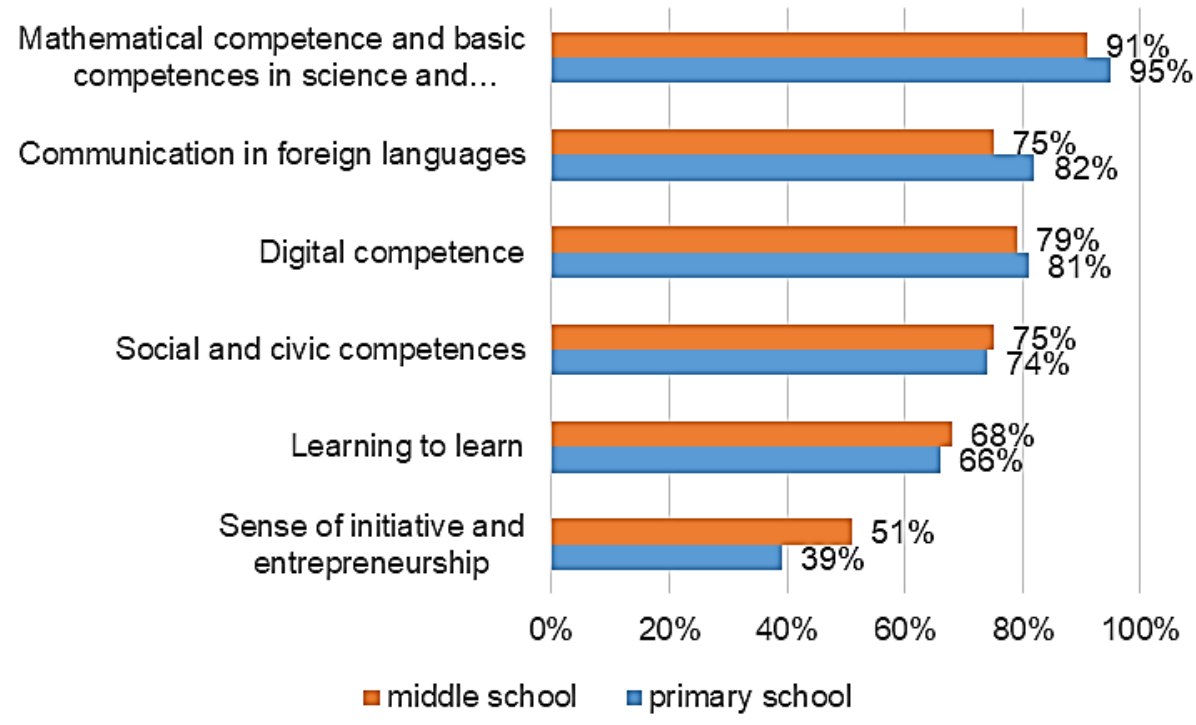

Figure 5. Types of shaped competences according to the declaration of the surveyed schools. Adapted from: Assessment of efficiency and effectiveness of support provided under the sub-measure 3.2.1. Quality of general education Regional Operational Program of Pomeranian Voivodeship for the years 2014-2020. Final report, EVALU Sp. z o.o., Gdańsk 2018, p. 73. 
Researches (Figure 6) indicates that participation of students in pro-educational initiatives has significantly influenced the increase of motivation and self-confidence. Children acted more creatively and independently. The declared effects of activities in both groups were similar except:

- increase of interest in subject competitions, where more activity was observed among younger students,

- economic awareness which was higher among older students.

Improvement was observed in many categories relevant to the education of e-leaders (Figure 6, shady parts), whose economy will particularly demand after dynamic changes on labor market. E-leader is a person with outstanding digital, business and management skills. E-leader combines statistical skills, including analysis of large data sets, correctly interprets the results of analyzes in the context of broader social trends. Market trends are therefore a chance for creative sociologists and economists ${ }^{6}$.

\begin{tabular}{|l|c|c|}
\hline \multicolumn{1}{|c|}{ Effects of project activities } & $\begin{array}{c}\text { primary } \\
\text { school }\end{array}$ & $\begin{array}{c}\text { middle } \\
\text { school }\end{array}$ \\
\hline Increase in motivation and self-confidence in learning & $80 \%$ & $77 \%$ \\
\hline More frequent search for own ways to solve logical problems & $72 \%$ & $71 \%$ \\
\hline Improving internet search skills & $71 \%$ & $72 \%$ \\
\hline Improving the understanding of read, spoken, written, spoken or heard text & $63 \%$ & $57 \%$ \\
\hline Improving functioning in a peer environment & $55 \%$ & $56 \%$ \\
\hline Increased awareness of the risks associated with the use of internet technologies & $63 \%$ & $58 \%$ \\
\hline Increased interest in participating in subject competitions & $58 \%$ & $48 \%$ \\
\hline Greater successes in subject competitions & $35 \%$ & $34 \%$ \\
\hline Increase in the number of students initiatives & $36 \%$ & $38 \%$ \\
\hline Increase in the level of understanding of cultural differences & $30 \%$ & $27 \%$ \\
\hline Increased awareness of the value of money, saving, self-employment & $17 \%$ & $29 \%$ \\
\hline Reducing the number of students incidents of aggression & $21 \%$ & $26 \%$ \\
\hline Less absenteeism at school & $9 \%$ & $11 \%$ \\
\hline
\end{tabular}

Figure 6. Effects of actions in shaping key competences. Adapted from: Assessment of efficiency and effectiveness of support provided under the sub-measure 3.2.1. Quality of general education Regional Operational Program of Pomeranian Voivodeship for the years 2014-2020. Final report, EVALU Sp. z o.o., Gdańsk 2018, p. 74.

Creativity and innovation of students were a separate support area. Competences in this field correspond to the key ones, especially to the initiative and entrepreneurship. Research shows that the following activities have had the greatest impact on these competences:

- cooperation of schools with the external environment, including universities,

- teaching in the area of natural sciences with the use of age-appropriate teaching tools and aids,

- developing competences in the field of science and mathematics.

\footnotetext{
${ }^{6}$ The author extensively deals with the topic in: Children's economic education - are we educate e-leaders? European Journal of Service Management Vol. 27/2, 3/2018, University of Szczecin 2018.
} 
Interestingly, the improvement of teachers' professional skills and competences was found to be the least important for shaping the creativity and innovation of students. In conclusion, within the framework of educational projects implemented in Pomeranian Voivodeship, the main emphasis was placed on the development of key competences, mostly students, and to a lesser extent - teachers. The interest in particular competences varied (39-95\%). Similarly, the effects of undertaken measures were assessed as their impact on the attitudes of students in selected areas.

\section{Development of competences among children - case studies}

For the purposes of this work, two case studies were selected in which ways of developing competences among children were analyzed and the results of these activities - two municipalities with more and less extensive network of schools. The content of this chapter is a refinement of the research presented earlier because selected entities took part in the evaluation study.

Two analyzed municipalities, diversified in size, come from the Bytów district. It was selected because it was the only one in the district group the most active in terms of educational activities, analyzed according to the following criteria:

- percentage of schools participating in the project to the total number of schools $>60 \%$ (Bytów, Człuchów, Kartuzy, Starogard districts).

- Percentage of primary schools participating in the project to the total number of primary schools $>60 \%$ (Bytów, Człuchów, Kartuzy, Starogard, Chojnice, Kościersko, Tczew, Pucko districts).

- percentage of junior high schools participating in the project to the total number of junior high schools $>60 \%$ (Bytów, Człuchów, Kartuzy, Starogard districts).

- percentage of upper secondary schools participating in the project to the total number of upper secondary schools $>60 \%$ (Bytów, Człuchów districts).

- high percentage of special schools to the total number of special schools (Bytów, Lębork, Nowy Dwór districts).

All of the desires key competences were shaped within the wide educational offer (Figure 7). Some of the classes were dedicated directly to students with special educational needs (SPE) in the field of equal opportunities. Students with special educational needs could also participate in other classes and were recruited on the basis of criteria indicated in the recruitment regulations (the received additional points for documented special educational needs). Some of the classes were carried out as a part of cooperation with the environment business incubator, university or library. 


\begin{tabular}{|c|c|}
\hline Type of classes * & Type of competences \\
\hline \multirow[t]{3}{*}{ Coding laboratory } & Mathematical and computer basics, science and technology \\
\hline & IT \\
\hline & Digital \\
\hline \multirow[t]{2}{*}{ Nature laboratory } & Mathematical and computer basics, science and technology \\
\hline & Learning \\
\hline Mathematics & Mathematical and computer basics, science and technology \\
\hline English by heart & Communication in foreign languages \\
\hline German by heart & Communication in foreign languages \\
\hline Master of memory & Learning \\
\hline English & Communication in foreign languages \\
\hline German & Communication in foreign languages \\
\hline Educational project & Social \\
\hline \multirow[t]{2}{*}{ Entrepreneurship using board games } & Social \\
\hline & Initiative and entrepreneurship \\
\hline Speech therapy classes $* *$ & Learning \\
\hline Compensatory and didactic classes $* *$ & Learning \\
\hline \multirow[t]{2}{*}{ Experimental day camps } & Mathematical and computer basics, science and technology \\
\hline & Learning \\
\hline \multirow[t]{4}{*}{ Day camps with robotics } & Mathematical and computer basics, science and technology \\
\hline & IT \\
\hline & Digital \\
\hline & Learning \\
\hline \multirow[t]{4}{*}{ Economic classes $* * *$} & Mathematical and computer basics, science and technology \\
\hline & Social \\
\hline & Initiative and entrepreneurship \\
\hline & Learning \\
\hline \multirow{3}{*}{ Competition related to entrepreneurship $* * *$} & Social \\
\hline & Initiative and entrepreneurship \\
\hline & Learning \\
\hline
\end{tabular}

Figure 7. Project offer and key competences. Adapted from: own study based on project data.

Figure 8 presents the scale of students' activity in the framework of individual types of classes in both municipalities (small and big one). In both cases, the vast majority of students from both municipalities took part in the project (big $-76 \%$, small $-71 \%$ ). The number of students participating in the particular classes was determined by the offer prepared under the project. It should be remembered that the offer was constructed on the basis of detailed diagnosis of the needs of individual schools. Therefore, it should be assumed that the type of activities and the scale of their impact were well suited to a given group. 


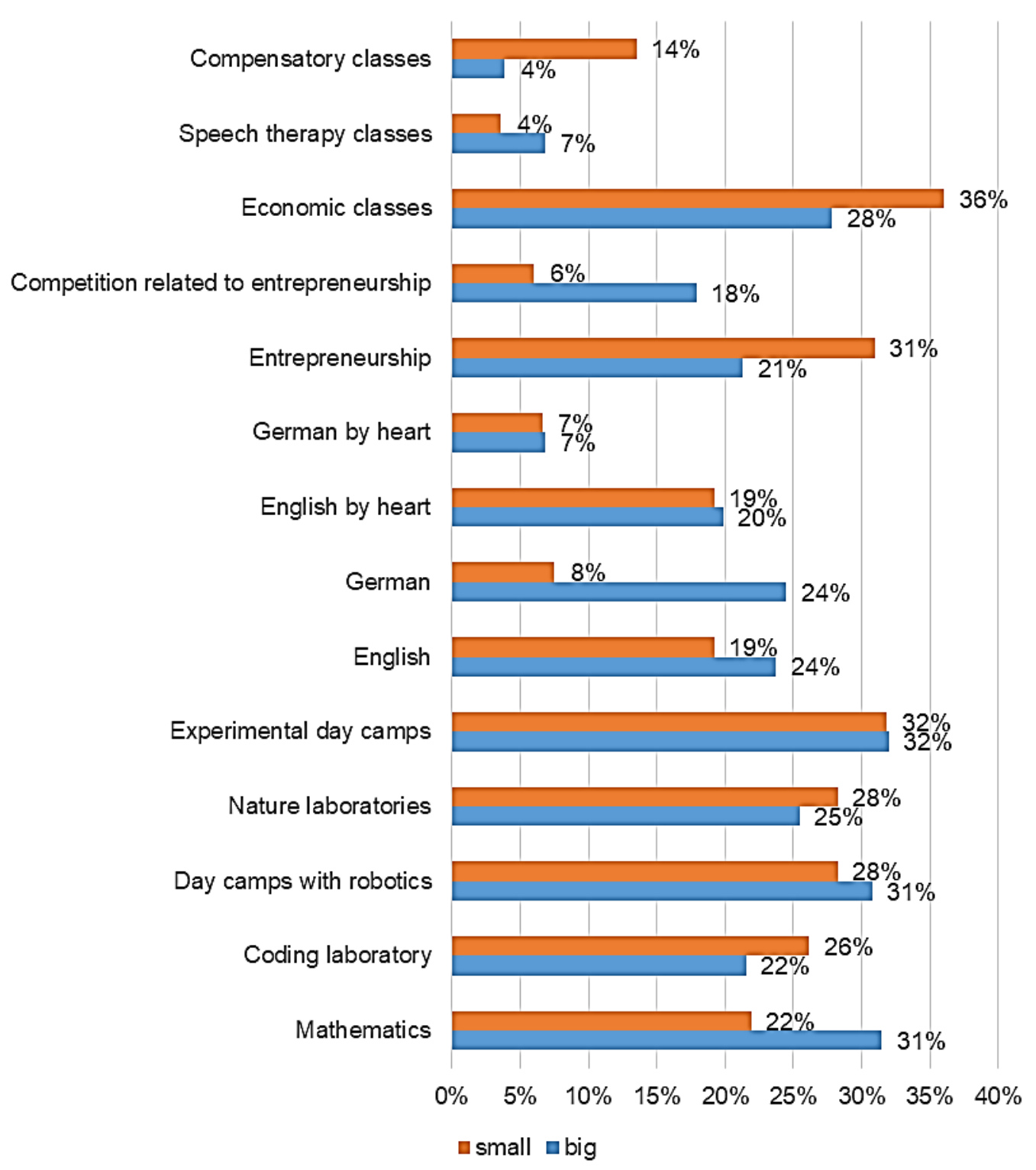

Figure 8. Percentage of students participating in individual classes in both districts (small one and big one). Adapted from: own study based on project data.

Particularly popular were the classes in an innovative practical form, i.e. summer classes, laboratories, Children's University. A significant number of children also took part in the language classes. The poorest was the offer of activities that equalize the chances of children with special educational needs. In almost all cases (big municipality 99\%, small 97\%) children increased their competences in at least one of the supported types - noted increase of knowledge had to be at least $30 \%$. The smallest progress in science is quite characteristic.

To summary, the detailed data are in line with the general regional trend. Their citation was aimed at indicating the specific methods and tools used by the project promoters to respond to local needs and to the needs of the region. At the same time, it should be in line with the direction of development established by the sponsor. 


\section{Conclusions and recommendations}

It is difficult to talk about effective investment in people without creating a base that will allow them to develop competences wider, more differently, as a part of exchange of experiences. Therefore, all project initiatives significantly equipped school institutions. The lack of modern teaching aids, including digital ones, is the schools' and teachers' biggest problem.

Similarly, in the scope of cooperation with the environment, a significant limitation is the lack of funds for costs related to such cooperation - travel expenses, ticket or reward costs.

The method of verifying the effects of undertaken initiatives also remains debatable. Assessing the level of knowledge before and after class to demonstrate the level of improvement (deterioration also happened) is not an optimal motivating factor. Carrot and stick method stands in contradiction to the values that are formed in children (later employees, entrepreneurs) within social competences development, which competences literature on the subject also consider to be crucial for the development of the economy.

The author also points out that in her opinion, special educational needs were satisfied to a relatively small extent in the undertaken activities. And children's special educational needs are observed more often. We are talking about the needs of children who need support. Gifted children had a separate range of activities. Compensatory classes were on offer in the vast minority. There were also no initiatives integrating and increasing children's awareness of differences in society, the possibility of cooperation beneficial for all parties and the moral obligation to help people who are weaker for various reasons. Investment in human capital on many levels is economically justified, especially in the context of benefits and indirect costs. Another study will be devoted to this issue.

The programme supporting the development of human potential at the stage of school education preferred investments in the development of key competences. In Pomeranian Voivodeship the following projects were implemented and evaluated out-of-school forms of education shaping most of the competences from the catalogue of the so-called key competences, although at different intensity. The focus was mainly on science and language competences, with the least focus on initiative and entrepreneurship, and too little attention paid to the special needs of pupils. Evaluation of effectiveness referred to the influence of particular forms of stimulation on the student's attitude in selected aspects. It was impossible to clearly attribute the impact of the investment on the results of exams summarizing a given stage of learning. 


\section{References}

1. Armstrong, M, and Brown, D. (2019). Strategic Human Resource Management: Back to the future? A literature review (Report No. 517). Brighton: Institute for Employment Studies.

2. Armstrong, M. (2001). Human resource management. Kraków: Oficyna Ekonomiczna, Dom Wydawniczy ABC.

3. Compare The European Social Fund. Investing in people. European Commission (2016).

4. Detailed Description of Priority Axis of Regional Operational Program of Pomeranian Voivodeship for the years 2014-2020.

5. Dubois, D.D., and Rothwell, W.J. (2018). Competency based human resource management. Gliwice: Wydawnictwo Helion.

6. Dyjak, G. Województwo pomorskie liderem $w$ realizacji Regionalnego Programu Operacyjnego. Retrieved from http://www.portalsamorzadowy.pl, 2019.08.24.

7. EVALU Sp. z o.o. (2018). Assessment of efficiency and effectiveness of support provided under the sub-measure 3.2.1. Quality of general education Regional Operational Program of Pomeranian Voivodeship for the years 2014-2020. Final report. Gdańsk.

8. Recommendation of the European Parliament and of the council of 18 December 2006 on key competences for lifelong learning (2006/962/EC).

9. Regional Operational Program of Pomeranian Voivodeship for the years 2014-2020.

10. Sienkiewicz, Ł. (2013). Competency-based human resource management. Warszawa.

11. Skweres-Kuchta, M. (2018), Children's economic education - are we educate e-leaders? European Journal of Service Management, DOI: 10.18276/ejsm.2018.27/2-46.

12. Skweres-Kuchta, M., Investment in key competences development among children and teenagers - case study, Ekonomiczne Problemy Usług. DOI: 10.18276/epu.2017.129-20. 